\author{
ŁUKASZ ChroboK, MARIAN H. LEWANDOWSKI \\ Zakład Neurofizjologii i Chronobiologii \\ Instytut Zoologii i Badań Biomedycznych \\ Wydziat Biologii \\ Uniwersytet Jagielloński $w$ Krakowie \\ Gronostajowa 9, 30-397 Kraków \\ E-mail: lukasz.chrobok@uj.edu.pl \\ marian.lewandowski@uj.edu.pl
}

\title{
WIELO-OSCYLATOROWA TEORIA MECHANIZMU ZEGARA BIOLOGICZNEGO SSAKÓW
}

\section{RYTMICZNOŚĆ ŚRODOWISKA JAKO EWOLUCYJNA POTRZEBA WYKSZTAECENIA ZEGAROWW BIOLOGICZNYCH}

Życie na Ziemi, w formie jaka możemy dziś obserwować, powstało w długotrwałym procesie ewolucji kształtowanej przez środowisko. Większość otaczających nas procesów nie przebiega w sposób ciagły, a powtarza się cyklicznie w wyniku obrotowego ruchu Ziemi wokół własnej osi, powodując rytmiczne, nieustanne nastepstwo dnia i nocy. Dlatego organizmy żywe wyewoluowały tak, aby nie tylko biernie odpowiadać na te zmiany, ale je przewidywać $i$ adekwatnie na nie reagować (MOORE-EDE 1986). Mechanizmy pozwalajace na antycypację cyklicznych zmian w środowisku nazywamy zegarami biologicznymi, a rytmy, których okres zbliżony jest do doby $(\sim 24 \mathrm{~h})$ rytmami okołodobowymi, czy cirkadialnymi (łac. circa - około, dies - dzień). U ssaków, w tym także u ludzi, rytmy okołodobowe możemy obserwować na każdym poziomie ich organizacji: od procesów molekularnych (ekspresja genów), przez procesy biochemiczne (np. metabolizm), do złożonych zachowań, takich jak sen czy pobieranie pokarmu. Dodatkowo, w fizjologii zwierząt można obserwować rytmikę w krótszej skali czasowej (ultradialnej; np. rytmiczne wydzielanie hormonów), jak i tej obejmujaccej wiele dni (infradialnej; np. rytmy miesięczne czy sezonowe) (LEWANDOWSKI 1999).
Zegar biologiczny ssaków synchronizuje się do zmiennego środowiska dzięki tak zwanym dawcom czasu (niem. Zeitgeber), z których najsilniejszym jest światło. Jednak nawet przy całkowitej izolacji od bodźców zewnętrznych, rytmika okołodobowa widoczna w fizjologii $\mathrm{i}$ zachowaniu nie zanika, a przebiega w okresie około $24 \mathrm{~h}$ dzięki pracy obecnego w mózgu endogennego generatora rytmów, jąder nadskrzyżowaniowych podwzgórza (ang. suprachiasmatic nuclei, SCN). U zwierzat nocnej aktywności (np. gryzoni laboratoryjnych), trzymanych w sztucznej dobie $12 \mathrm{~h}$ swiatła: $12 \mathrm{~h}$ ciemności (ang. light/dark; LD 12/12), większość zachowań, takich jak: aktywność lokomotoryczna, pobieranie pokarmu czy picie, odbywa się w fazie ciemnej. Faza jasna jest czasem ich odpoczynku, czyli snu. Jeśli jednak zostana one pozbawione dostępu do światła (stała ciemność, DD), rytmiczność tych procesów nie zanika, a jedynie zmienia nieznacznie swój okres i fazę, przyjmujacc tzw. rytm swobodnie biegnacy (ang. free running), co jest dowodem wewnętrznego (endogennego) pochodzenia tej rytmiczności. Co więcej, zwierzęta operacyjnie pozbawione SCN wykazuja rytmiczne zachowanie w warunkach LD, sa one jednak nierytmiczne w stałej ciemności. Rytmiczność ta może jednak zostać przywrócona po transplantacji SCN od innego zwierzęcia, do komory ich mózgowia (MOORE i EICHLER 1972, RALPH i MENAKER 1988, RALPH i współaut. 1990). 


\section{NEURONALNY I MOLEKULARNY MECHANIZM ODMIERZANIA CZASU PRZEZ GEÓWNY ZEGAR}

SCN to niewielka parzysta struktura neuronalna zlokalizowana w przedniej części podwzgórza, tuż nad skrzyżowaniem wzrokowym, w pobliżu komory trzeciej mózgowia. Dzięki bezpośredniemu unerwieniu przez wyspecjalizowane komórki siatkówki oka (światłoczułe komórki zwojowe produkujące fotopigment, melanopsynę), neurony $\mathrm{SCN}$ sa wrażliwe na zmiany oświetlenia środowiska. Światło nie jest jednak jedynym bodźcem mogacym wpływać na fazę aktywności SCN i innych struktur budujacych zegar biologiczny. Bodźce nieświetlne, takie jak dostępność pokarmu, temperatura czy interakcje socjalne, także synchronizują jego pracę dzięki unerwieniu SCN przez liczne struktury mózgowia, takie jak listek ciała kolankowatego wzgórza (ang. intergeniculate leaflet) czy jądra pnia mózgu (ABRAHAMSON i MOORE 2001, LEWANDOWSKI 2008, LUCAS 2013).

Precyzyjny system odmierzania czasu przez komórki SCN zapewnia samonapędzająca się pętla transkrypcyjno-translacyjna tzw. genów zegarowych, za opis której przyznano w 2017 r. nagrodę Nobla w dziedzinie fizjologii lub medycyny (GieBultowicz 2018). U ssaków, tę molekularna pętlę rozpoczyna połączenie się białek CLOCK i BMAL w cytoplazmie. Taki heterodimer transportowany jest następnie do jadra komórkowego, gdzie działajac jako czynnik transkrypcyjny, powoduje ekspresję genów Per i Cry. Produkty tych genow zegarowych, białka PERIOD i CRY akumuluja się w jadrze, hamujacc działanie CLOCK i BMAL, a tym samym swoja własną ekspresję. Cały cykl ekspresji genów zegarowych oraz gromadzenia i degradacji ich produktów trwa około 24h, co stanowi tzw. takt zegara, endogennie odmierzajacego czas w obrębie doby (GóRSKA-ANDRZEJAK 2011, TAKAHASHI 2017). Rytmiczna aktywność genów zegarowych jest ściśle sprzężona $z$ aktywnościa elektryczna neuronów SCN, które generują potencjały czynnościowe $Z$ wysoka częstotliwością w ciągu dnia i niska w nocy (COLLWEL 2011). Z drugiej strony, bodźce wpływajace na aktywność elektryczna neuronów SCN, takie jak puls światła w nocy, moga zmieniać ekspresję genów zegarowych i przesuwać fazę zegara. Rytm elektrofizjologiczny SCN jest niezmiernie ważnym sygnałem czasu okołodobowego dla innych części mózgowia, a także tkanek i organów całego ciała. Eksperymenty $z$ transplantacją SCN do komory mózgowia, przywracaja większość rytmów behawioralnych i pokazują wyraźnie, że połaczenia neuronalne nie sa jedyna droga przekazywania informacji o czasie okołodobowym do tkanek peryferycznych (obwodowych). Rzeczywiście, komórki SCN wydzielaja lokalnie do płynu mózgowo-rdzeniowego komory trzeciej mózgowia takie substancje jak wazopresyna czy prokinetycyna 2, których rytmiczna synteza jest również pod ścisła kontrola genów zegarowych. Przypuszcza się, że substancje te, pojawiajace się $\mathrm{w}$ płynach fizjologicznych jedynie $\mathrm{w}$ określonym oknie czasowym doby, moga być powolnym i trwałym sygnałem o fazie cyklu dobowego dla reszty organizmu (CHENG i współaut. 2002, HASTINGs i współaut. 2018).

\section{CZY TYLKO JEDEN ZEGAR?}

Dotychczasowa, klasyczna teoria zegara biologicznego zakładała, że endogenna i rytmiczna ekspresja genów zegarowych zachodzi tylko w obrębie SCN. Ostatnie lata dostarczyły jednak danych, które poddaja w watpliwość istnienie modelu ograniczonego tylko do jednego oscylatora. Rozwój i zastosowanie nowych technik molekularnych i obrazowania $w$ badaniu mechanizmu zegara biologicznego, wykazały autonomiczna ekspresję genów zegarowych również w innych, niż SCN strukturach mózgu, a także tkankach i narzadach peryferycznych (GuILDING i Piggins 2007, PAUL i współaut. 2019). Przełomem było stworzenie modelu mysiego PER2::LUC, w którym wraz $z$ ekspresja genu Per2 dochodzi do ekspresji białka fuzyjnego lucyferazy, enzymu wyizolowanego ze świetlika Photinus pyralis. Enzym ten katalizuje utlenianie lucyferyny, któremu towarzyszy wydzielenie fotonu (bioluminescencja), a więc świecenie (Yoo i współaut. 2004). Skrawki przygotowane $z$ takiego modelu zwierzęcego, hodowane ex vivo $\mathrm{w}$ pożywce $\mathrm{z}$ lucyferyna, zawierajace struktury, w których zachodzi rytmiczna ekspresja genów zegarowych, charakteryzuja się rytmicznym świeceniem przez wiele dni, a nawet tygodni (ABE i współaut. 2002).

Niewatpliwie, SCN jest jednym $z$ najsilniejszych oscylatorów okołodobowych w mózgowiu. Jego rytm w warunkach ex vivo charakteryzuje wysoka amplituda (duża zmienność między dniem a noca) oraz powolny zanik, co wskazuje na jego trwałość. Poza tym, pojedyncze komórki zegarowe SCN sa ze soba silnie zsynchronizowane, a synchronizacja ta zanika bardzo wolno w czasie, utrzymując się $w$ hodowli nawet kilka tygodni. Innymi nowoodkrytymi endogennymi oscylatorami, niezależnymi od SCN (ang. extra-SCN oscillators) są: opuszki węchowe, jądra uzdeczki, przyśrodkowo-podstawne podwzgórze (w tym jadro grzbietowo-przyśrodkowe czy łukowate), narządy okołokomorowe przodomózgowia (narząd podskle- 


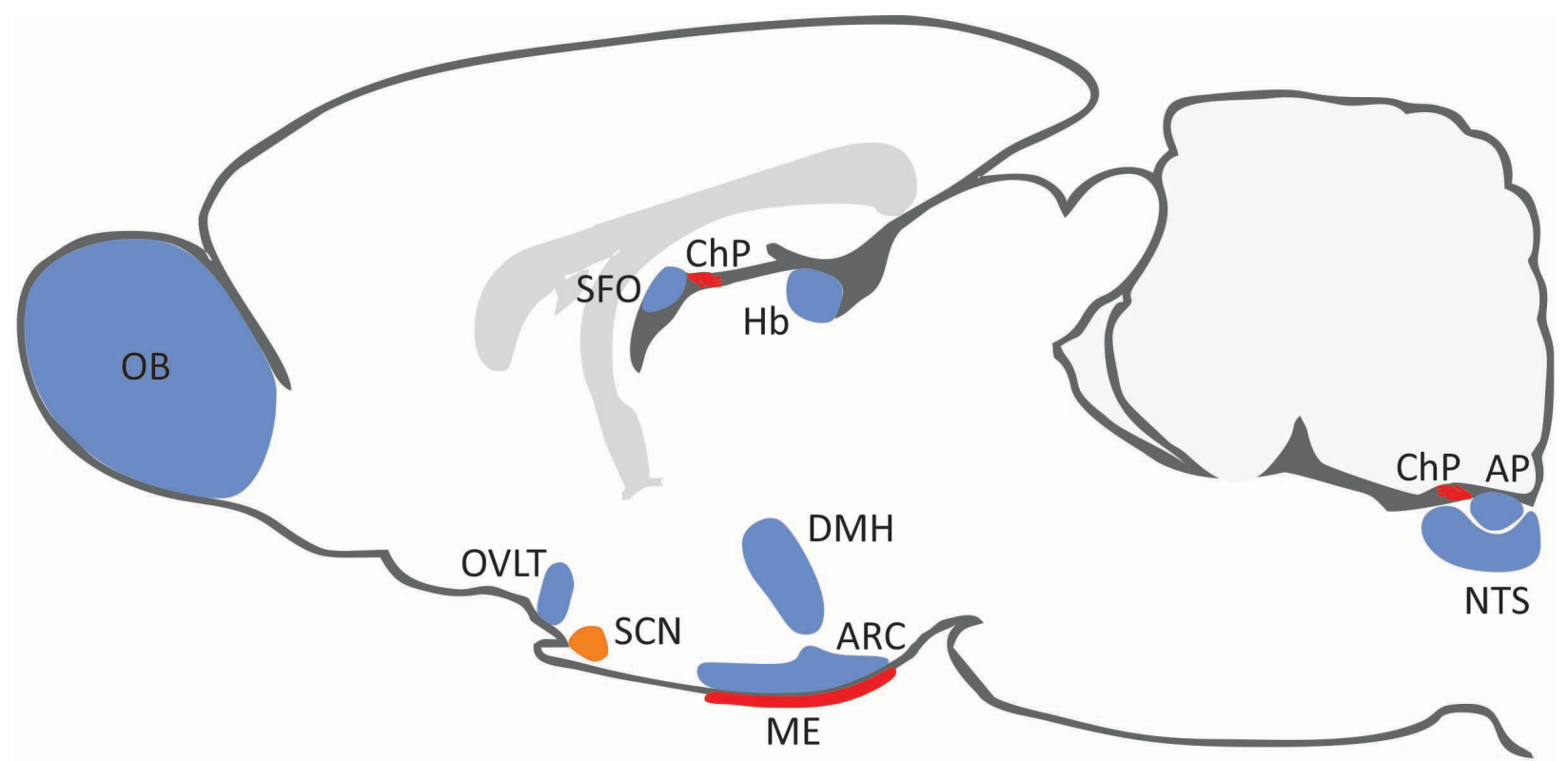

Ryc. 1. Schemat strzałkowy mózgu szczura obrazujący lokalizację nowoodkrytych endogennych oscylatorów okołodobowych opisanych w tekście, w relacji do jąder nadskrzyżowaniowych (na pomarańczowo).

$\mathrm{Na}$ niebiesko zaznaczono oscylatory neuronalne, na czerwono - glejowe. ARC - jadra łukowate (ang. arcuate nuclei); AP - miejsce najdalsze (ang. area postrema); ChP - splot naczyniówkowy (ang. chorois plexus); DMH - grzbietowo-przyśrodkowe jądra podwzgórza (ang. dorso-medial hypothalamus); Hb - uzdeczka (ang. habenula); ME - wyniosłość pośrodkowa (ang. median eminence); NTS - jądro pasma samotnego (ang. nucleus of the solitary tract); OB - opuszka węchowa (ang. olfactory bulb); OVLT - narząd naczyniowy blaszki krańcowej (ang. vascular organ of lamina terminalis); SCN - jądra nadskrzyżowaniowe (ang. suprachiasmatic nuclei); SFO - narząd podsklepieniowy (ang. subfornical organ).

pieniowy, wyniosłość pośrodkowa i narząd naczyniowy blaszki krańcowej) i tyłomózgowia (miejsce najdalsze) czy jądro pasma samotnego w pniu mózgu (Ryc. 1). Silna, rytmiczną ekspresję genów zegara zaobserwowano również poza ośrodkowym układem nerwowym $\mathrm{w}$ narzadach peryferycznych, takich jak watroba, nerki czy płuca. Nowa, wielo-oscylatorowa teoria zegara biologicznego zakłada, że przynajmniej część rytmicznej kontroli procesów fizjologicznych jest zdecentralizowana i ograniczona do tych stosunkowo nowoodkrytych lokalnych oscylatorów (DiBner i współaut. 2010, ALBRECHT 2012).

\section{OPUSZKA WECHOWA JAKO SILNY OSCYLATOR NIEZALEŻNY OD SCN}

Opuszka węchowa gryzoni była jedna z pierwszych struktur poza SCN, w której zarejestrowano okołodobowe pozaustrojowe oscylacje ekspresji genów zegarowych, trwające kilka dni. Opuszka węchowa to struktura neuronalna w ośrodkowym układzie nerwowym, położona w wysuniętej rostralnie części przodomózgowia (Ryc. 1). Jest ona szczególnie uwydatniona u gryzoni, których zachowania pokarmowe i socjalne silnie zależą od bodźców węchowych. Odbiera ona informacje zmysłowe (węchowe: zapach) $\quad$ receptorów zlokalizowanych $\mathrm{w}$ nabłonku węchowym jamy nosowej, a następnie przesyła je do formacji hipokampa, jąder migdałowatych czy kory przedczołowej, tworzac ślady pamięciowe i emocjonalne wywołane zapachami. Już pierwsze badania chronobiologiczne tej struktury wykazały, że jej neurony charakteryzuje silna, niezależna od SCN ekspresja genów zegarowych (GRANADOS-FUENTES i współaut. 2004a). Jest ona obecna nawet w warunkach stałego oświetlenia (LL), które w SCN powoduja zanik rytmów molekularnych (GRANADOS-FuENTES i współaut. 2004b). Dodatkowo, rytmicznej ekspresji genów zegarowych w opuszce węchowej towarzyszy okołodobowa rytmika aktywności neuronalnej, co może sugerować, że informacja o czasie okołodobowym jest przekazywana do innych, unerwianych przez nia struktur mózgowych. Funkcjonalnie, obecność endogennych oscylacji w opuszce węchowej jest podłożem okołodobowej zmiany wrażliwości na zapachy (GRANADOS-FuENTES i wspólaut. 2006). U gryzoni zmysł węchu jest najbardziej wyostrzony w połowie nocy, fazie aktywnej tych zwierzat. Nowsze badania wskazuja, że zegar w opuszce węchowej może być synchronizowany do zmian środowiska, jednak w inny 
sposób, niż to obserwujemy w SCN. Reaguje on przesunięciem fazy rytmu na zmianę czasu podawania pokarmu (jedzenia), a nie zmianę oświetlenia. Interesujące i ciekawe jest, że nawet przy uszkodzonym nabłonku węchowym, pokarm jest $\mathrm{w}$ stanie nadal nastawiać (regulować) rytm zegara (NoLASCO i współaut. 2012, PAVLOVSKI i współaut. 2018). Może to sugerować istnienie bardziej złożonych neuronalno-hormonalnych mechanizmów regulacji okołodobowych oscylacji w ośrodkowej części układu węchowego. Podsumowując, badania opuszki węchowej były pierwszymi, które zakwestionowały dominujacy i samotny udział SCN w okołodobowej rytmice kontroli procesów fizjologicznych. Spożywanie pokarmu, któremu towarzyszy specyficzne zachowanie pokarmowe, zależne także od rytmicznej wrażliwości węchowej, jest bardzo ważna potrzebą fizjologiczną organizmu. Nie dziwi zatem odrębność mechanizmu jego okołodobowej regulacji od głównego generatora rytmów biologicznych. Jest to również pewnego rodzaju „zabezpieczenie biologiczne" utrzymania organizmu przy życiu w wypadku uszkodzenia SCN.

\section{JĄDRA UZDECZKI I OKOŁODOBOWA KONTROLA NASTROJU}

Innym silnym oscylatorem okołodobowym niezależnym od SCN sa jądra uzdeczki. Jest to parzysta struktura położona w linii środkowej nadwzgórza (grzbietowej części wzgórza), tuż pod szyszynka, podzielona na dwie główne części: boczna i przyśrodkowa (Ryc. 1). Funkcjonalnie, jądra uzdeczki biora udział w przetwarzaniu bodźców bólowych, wzmocnieniu awersyjnym (ważnym w wygaszeniu reakcji warunkowej), uzależnieniach i odpowiedzi stresowej, a także $\mathrm{w}$ procesach uczenia, uwagi, reprodukcji czy odżywiania. Sugeruje się także ich udział w kontroli rytmu snu i czuwania, przez wpływ na aktywność układów monoaminergicznych pnia mózgu. Jednak co najważniejsze w kontekście tego artykułu, jądra uzdeczki uznaje się za ważny element zegara biologicznego (BAÑo-Otalora i Piggins 2017). Pierwsze doniesienia dotyczace jąder uzdeczki w kontekście rytmów okołodobowych wynikały $z$ ich bezpośredniego unerwienia przez SCN. Pokazano także, że ich aktywność elektryczna in vivo charakteryzuje się rytmika okołodobową. Wykazano także, że u gryzoni wrażliwość neuronów uzdeczki na bodźce świetlne rośnie w nocy, w fazie aktywności zwierzęcia, co wynika $z$ jej anatomicznego pośredniego połaczenia $z$ siatkówka oka (ZHAO i RUSAK 2005). Podobnie jak w przypadku opuszki węchowej, jądra uzdeczki wyznaczaja czas okołodobowy nawet $\mathrm{w}$ hodowlach skrawko- wych ex vivo $\mathrm{w}$ zupełnej izolacji od głównego zegara. Jest to efekt własnej, endogennej ekspresji genów zegarowych, szczególnie silnej w przyśrodkowej granicy bocznej uzdeczki. Rytmiczna ekspresja genów zegarowych utrzymuje się nawet po zablokowaniu wzajemnej komunikacji między neuronami tej struktury, poprzez podanie do pożywki hodowlanej tetrodotoksyny, blokera napięciowo-zależnych kanałów sodowych. Taka manipulacja eksperymentalna, poprzez zablokowanie generowania potencjałów czynnościowych, uniemożliwia komunikację pomiędzy poszczególnymi neuronami $\mathrm{w}$ tej strukturze. Tak więc, nawet pojedyncze neurony jąder uzdeczki, w warunkach farmakologicznej izolacji, sa w stanie utrzymać wewnętrzna okołodobowa oscylacje, zachowujac tym samym możliwość ciagłego odmierzania czasu (GuILDING i współaut. 2010). Również aktywność elektryczna neuronów uzdeczki w warunkach pozaustrojowych (ex vivo), czyli w pełnej izolacji od SCN, utrzymuje okołodobowy rytm, osiagajac maksimum $\mathrm{w}$ nocy (SAKHI i współaut. 2014a, b). Szczególnie istotnymi sa badania potwierdzajace obecność rytmicznej aktywności uzdeczki u ludzi. Najnowsze doniesienia pokazuja, że struktura ta mocniej reaguje na szkodliwy dla naszego nastroju niedobór światła rano, niż wieczorem (KAISER i współaut. 2019). Wyniki te otwieraja zupełnie nowe perspektywy badawcze i terapeutyczne, uwzględniające światło i jądra uzdeczki jako kluczowe w kontroli nastroju. $U$ pacjentów $z$ depresja zauważono zmniejszenie jader uzdeczki, a fototerapia depresji opiera się między innymi na pobudzeniu aktywności właśnie tej części mózgowia (HUANG i współaut. 2019). Dlatego, znajomość chronobiologicznych mechanizmów funkcjonowania tej ważnej klinicznie struktury neuronalnej pozwala na lepsze planowanie terapii zaburzeń nastroju, w tym depresji. Dodatkowo, wskazuje na istotna rolę porannego dostępu do światła w kontroli nastroju.

\section{PODWZGÓRZOWE OSCYLATORY OKOEODOBOWE}

Jądra nadskrzyżowaniowe to nie jedyne oscylatory okołodobowe obecne w obszarze podwzgórza, stosunkowo starej ewolucyjnie części układu nerwowego, odpowiedzialnej za utrzymanie prawidłowej homeostazy organizmu. Jądra podwzgórza sa aktywowane przez bodźce związane $\mathrm{z}$ pobieranie pokar$\mathrm{mu}$, osmoregulację, termoregulację, metabolizm, zachowania seksualne i wiele innych procesów. Badania $z$ użyciem modelu mysiego PER2::LUC pokazały, że dwa jądra podwzgórza umiejscowione $\mathrm{w}$ jego podstawno-przyśrodkowej części, sa szczególnie sil- 


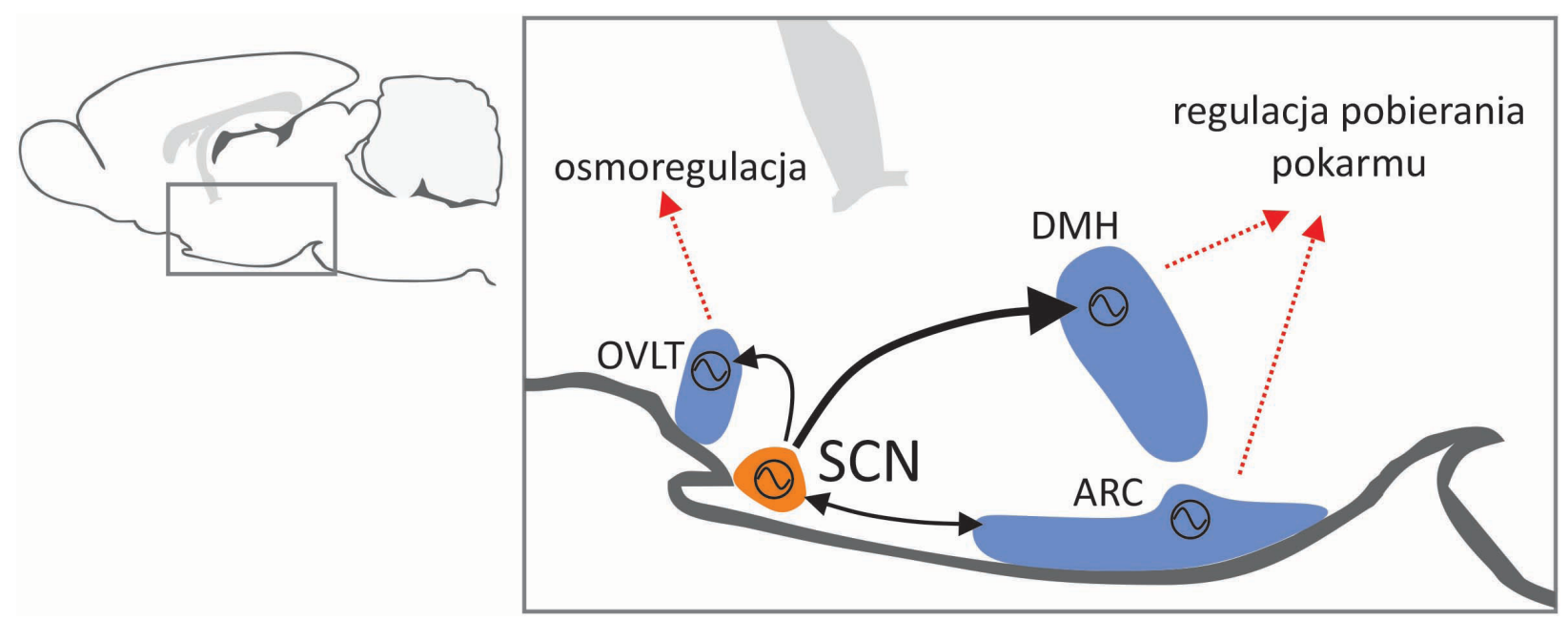

Ryc. 2. Schemat mózgu szczura pokazujący wybrane połaczenia neuronalne SCN z innymi oscylatorami okołodobowymi.

ARC - jądra łukowate (ang. arcuate nuclei); DMH - grzbietowo-przyśrodkowe jądra podwzgórza (ang. dorso-medial hypothalamus); OVLT - narzą naczyniowy blaszki krańcowej (ang. vascular organ of lamina terminalis); SCN - jądra nadskrzyżowaniowe (ang. suprachiasmatic nuclei).

nymi generatorami rytmów okołodobowych niezależnymi od SCN (GUILDING i współaut. 2009). Pierwszym $z$ nich jest struktura bezpośrednio związana $z$ regulacją pobierania pokarmu, zwana jądrami łukowatymi (ang. arcuate nuclei). Sa to niewielkie skupiska neuronów w okolicach komory trzeciej mózgowia i wyniosłości pośrodkowej. Ich lokalizacja anatomiczna i projekcje pozwalaja na pełnienie przez nie funkcji neuroendokrynnych. W obrębie jąder łukowatych znajduja się komórki syntetyzujace neuropeptyd $\mathrm{Y}$ i białko aguoti (AgRP), które sa pierwszorzędowymi neuronami głodu, oraz komórki syntetyzujace proopiomelanokortynę (POMC) i transkrypt zależny od kokainy i amfetaminy (CART), czyli pierwszorzędowe neurony sytości. Praca tych jąder w sposób kompleksowy kontroluje zachowania pokarmowe, które wykazuja wyraźna zmienność okołodobową. Gryzonie i inne ssaki o aktywności nocnej w większości spożywają pokarm w fazie ciemnej. Faza jasna jest dla nich czasem odpoczynku (snu), a ich metabolizm jest wtedy bardzo spowolniony. I odwrotnie, zwierzęta o aktywności dziennej, w tym ludzie, jedza (a przynajmniej, w zgodzie ze swoja fizjologia, powinni) w ciagu dnia, czyli w fazie jasnej. Ta rytmiczność w zachowaniach pokarmowych ma swoje odzwierciedlenie w rytmicznej pracy jąder łukowatych. Pokazano silny, endogenny rytm ekspresji genów zegarowych w komórkach tej struktury, utrzymujacy się nawet $\mathrm{w}$ warunkach hodowli ex vivo, czyli niezależny od aktywności SCN. Dodatkowo, rytmice na poziomie molekularnym towarzyszy znacząca okołodobowa zmienność aktywności elektrycznej neuronów jądra łukowatego. Oprócz wyraźnych endogennych właściwości zegarowych tej struktury, jądra łukowate sa anatomicznie i funkcjonalnie połaczone z SCN (Ryc. 2). Mogą być zatem nie tylko dostrajane do rytmu głównego oscylatora, ale także wpływać na jego prace $\mathrm{w}$ zależności od metabolicznych potrzeb organizmu (CHALLET 2019).

Kolejnym, niezależnym od SCN, endogennym okołodobowym oscylatorem podwzgórza jest jądro grzbietowo-przyśrodkowe (ang. dorsomedial hypothalamus). Jego rytmiczna aktywność rejestrowana jest zarówno w ekspresji genów zegarowych, jak i zmiennej okołodobowo neuronalnej aktywności elektrofizjologicznej (GUILDING i współaut. 2009). Jest ono zaliczane do drugorzędowych ośrodków kontroli przyjmowania pokarmu, które odbiera informacje $z$ pierwszorzędowych neuronów zlokalizowanych $\mathrm{w}$ jądrach łukowatych. Jąra grzbietowo-przyśrodkowe podwzgórza sa jednym $z$ najgęściej unerwianych bezpośrednio przez komórki SCN obszarów mózgowia, choć same nie unerwiaja go zwrotnie (Ryc. 2). Połaczenie to jest niezbędne dla wielu rytmicznych procesów fizjologicznych, gdyż jądra te bezpośrednio unerwiaja obszary mózgowia odpowiedzialne za osmoregulację, regulację wydatku energetycznego, czy sen. Istotna, odmienna od SCN, właściwościa tych jąder jest zależność ich neuronalnej aktywności od dostępności pokarmowej, a nie światła. Ta elastyczna, utrwalona ewolucyjnie zmienność, zabezpiecza pokarmowo organizmy poprzez odwrócenie (nawet o $180^{\circ}$ ) fazy ich aktywności 
ruchowej, $z$ nocnej na dzienną. Tak jest w przypadku niektórych gatunków zwierząt, dla których pora pojawiania się pokarmu zmienia się w zależności od pory roku $z$ nocnej na dzienna (GoOLey i współaut. 2006). Podsumowując, rytmika okołodobowa grzbietowo-bocznego podwzgórza może być konieczna w prawidłowym przygotowaniu organizmu do spożywania pokarmu o różnych porach doby, $z$ uwzględnieniem pory roku. Oznacza to nie tylko wykształcenie we właściwym czasie uczucia głodu i sytości, ale także przygotowanie odpowiedniego tła hormonalnego i poziomu metabolizmu do przyjmowania pożywienia. Zaburzenie tych procesów fizjologicznych, a w konsekwencji spożywanie pokarmu o nieprawidłowej porze doby, prowadzi do chorób metabolicznych, sercowo-naczyniowych i otyłości, współcześnie bardzo powszechnych chorób cywilizacyjnych (CHALLET 2015).

\section{OKOŁODOBOWA KONTROLA GOSPODARKI WODNEJ - GEÓWNA FUNKCJA ZEGARA?}

Procesy służące utrzymaniu prawidłowej osmolarności (zagęszczenia) płynów fizjologicznych, a więc gospodarki wody w organizmie, sa kluczowe nie tylko dla właściwej homeostazy, ale także do przeżycia. Dlatego ssaki wykształciły szereg mechanizmów, które kieruja zachowaniem pobierania wody (piciem), utrzymaniem stałej osmolarności krwi, płynów tkankowych (w tym płynu mózgowo-rdzeniowego), jak i jej utrata (perspiracja, diureza). Okołodobowy rytm snu i czuwania czasowo reguluje i ogranicza dostęp do wody. Jest ona dostępna i głównie spożywana w fazie aktywnej zwierzat, a zdecydowanie ograniczona podczas ich fazy odpoczynku (snu). Utrzymywanie przez cała dobę parametrów osmotycznych płynów ustrojowych na fizjologicznym poziomie, regulowane jest także przez zegar biologiczny, który przewiduje nadejście fazy nieaktywnej, w której zwierzę śpi, i tym samym powstrzymuje się od picia. U gryzoni, pod koniec fazy aktywnej obserwuje się antycypacyjne picie wody (ponad miarę), mimo iż $\mathrm{w}$ tym momencie doby nie jest ona potrzebna dla zachowania homeostazy (GIZOWSKI i współaut. 2016, GIZOWSKI i BOURQUE 2017).

Miejscem w ośrodkowym układzie nerwowym, które nieustanie monitoruje skład i osmolarność płynów ustrojowych (krwi i płynu mózgowo-rdzeniowego) sa tak zwane zmysłowe narządy okołokomorowe; obszary mózgowia zlokalizowane w płaszczyźnie pośrodkowej mózgu, niejako zawieszone w komorach mózgowia. Do zmysłowych narząów okołokomorowych zaliczamy: narząd podsklepieniowy (komora trzecia mózgu, przodomózgowie), narząd naczyniowy blaszki krańcowej (przednia ściana komory trzeciej, przodomózgowie) i miejsce najdalsze (tylna ściana komory czwartej, tyłomózgowie) (Ryc. 1). Obszary te maja specyficzna budowe; zawieraja bardzo dużo wyspecjalizowanych komórek glejowych, gęsto upakowane neurony i sa silnie unaczynione. Najważniejsza cecha narządów okołokomorowych jest rozszczelniona bariera krew-mózg, co pozwala zawartym w nich komórkom na bezpośrednie monitorowanie penetrujących w głąb narządu cząsteczek $Z$ krwi obwodowej. Z drugiej jednak strony, narzady te otoczone sa ścisła bariera glejowa, która uniemożliwia „rozlewanie się" substancji pochodzacych $z$ krwi do otaczajacych je ośrodków neuronalnych czy płynu mózgowo-rdzeniowego (LANGLET i współaut. 2013). Fizjologiczne znaczenie narządów okołokomorowych polega na rejestracji zmian osmolarności krwi i adekwatna na nie reakcji poprzez modyfikację zachowań zwiazanych $z$ pobieraniem wody, jej piciem przez zwierzęta (MCKINLEY i współaut. 2003).

Wyniki ostatnich badań pokazały, że neurony wazopresynowe SCN unerwiaja narząd naczyniowy blaszki krańcowej i sa bezpośrednio odpowiedzialne za codzienne wywoływanie antycypacyjnego picia pod koniec fazy aktywnej (Ryc. 2). Zahamowanie tego neuronalnego połaczenia u gryzoni o aktywności nocnej powoduje, że zwierzęta nie pija "na zapas” przed nastaniem behawioralnie nieaktywnego dnia. Tym samym, parametry fizjologiczne zwiazane $z$ osmolarnościa krwi ulegaja drastycznemu pogorszeniu podczas snu. Dodatkowo, najnowsze doniesienia pokazują, że zmysłowe narządy okołokomorowe sa niezwykle silnymi endogennymi oscylatorami okołodobowymi, a rytmiczna ekspresja ich genow zegarowych utrzymuje się nawet przez trzy tygodnie w hodowli ex vivo, w warunkach pełnej izolacji od SCN (NORTHEAST i współaut. 2019). Można więc postawić hipotezę, że nie tylko sygnał $z$ głównego zegara kontroluje zachowania pobierania wody, ale także narządy okołokomorowe sa na ten okołodobowy sygnał przygotowane, same regulujac okołodobowa ekspresję rozmaitych receptorów i kanałów jonowych. Podobnie jak w przypadku opuszki węchowej i okołodobowej regulacji zachowań pokarmowych, silny endogenny zegar okołodobowy w ośrodkach mózgu bezpośrednio kontrolujacych gospodarkę wodną, może być zabezpieczeniem ewolucyjnym w przypadku utraty lub nieprawidłowego funkcjonowania SCN, szczególnie, że zaburzenia picia moga w krótkim czasie prowadzić do poważnych konsekwencji zdrowotnych, a nawet zagrażać życiu (Gizowski i współaut. 2016). 
Nerki są drugim (po wątrobie) najsilniejszym zegarem okołodobowym znajdujacym się poza układem nerwowym. Zegar w nerkach kontroluje ekspresję wielu genów, przyczyniając się do wyraźnego okołodobowego rytmu regulacji osmolarności krwi przez te organy. Zależność między rytmika okołodobowa a praca nerek jest jednak dwustronna: upośledzenie ekspresji genów zegara prowadzi do zmian osmolarności krwi, a choroby nerek powoduja zaburzenia rytmu snu i czuwania (MYUNG i wspó1aut. 2019). Obecność endogennych zegarów okołodobowych na wszystkich poziomach szlaków neuronalnych kontrolujacych picie, bezpośrednie zaangażowanie SCN w antycypacyjny pobór wody przed snem oraz istnienie autonomicznego, stosunkowo silnego peryferycznego zegara okołodobowego w nerce pokazuja, że dobowa kontrola gospodarki wodnej jest jedna $z$ podstawowych funkcji zegara biologicznego ssaków.

\section{WIELO-OSCYLATOROWY OŚRODEK ODMIERZAJĄCY CZAS W PNIU MÓZGU}

Pień mózgu jest ewolucyjnie najstarsza częścia mózgowia kręgowców, a jego praca jest niezbędna do przeżycia. Ośrodki neuronalne pnia mózgu reguluja podstawowe procesy życiowe takie jak: oddychanie, rytm serca, wrodzone odruchy (ssanie, mruganie, połykanie), sen i czuwanie, czy przy współpracy $z$ podwzgórzem - zachowania pokarmowe. Dotychczas, wszystkie zegary okołodobowe mózgowia opisywane były w ewolucyjnie młodszym przodomózgowiu, jednak najnowsze badania pokazuja, że właściwości zegarowe można też przypisać kompleksowi ściśle współpracujących ze soba struktur neuronalnych w tyłomózgowiu, zwanych grzbietowym kompleksem nerwu błędnego (ang. dorsal vagal complex) (Ryc.1). W jego skład wchodzą: (1) miejsce najdalsze (ang. area postrema) - zmysłowy narząd okołokomorowy monitorujacy nie tylko osmolarność płynów ustrojowych, ale także zawartość substancji toksycznych we krwi, odpowiedzialny za uczucie nudności i odruch wymiotny; (2) jadro pasma samotnego (ang. nucleus of the solitary tract) - ośrodek integrujacy obwodowe $\mathrm{i}$ ośrodkowe informacje metaboliczne, pokarmowe (dot. głodu i sytości) i sercowo-naczyniowe, aby w koordynacji $z$ jądrami podwzgórza specyficznie modulować zachowania pokarmowe; (3) grzbietowe ruchowe jądro nerwu błędnego (ang. dorsal motor vagus) - struktura neuronalna będacca „wyjściowa” dla całego kompleksu, w której zlokalizowane sa ciała komórek, których to aksony opuszczają pień mózgu tworząc nerw błędny (GRILL i HAYES 2012). Ze względu na to, że nerw błędny tworzy układ przywspółczulny, regulujący pracę wielu narząów ciała w klatce piersiowej i jamie brzusznej, prawidłowa praca grzbietowego kompleksu nerwu błędnego jest konieczna do utrzymania fizjologicznego funkcjonowania całego organizmu.

Praca narządów unerwianych przez nerw błędny (np. praca serca, oddychanie, procesy trawienne), jak i procesy regulowane przez miejsce najdalsze (pobieranie wody) i jadro pasma samotnego (pobieranie pokarmu) wykazuja silne zróżnicowanie dobowe. Dlatego zasadnym ewolucyjnie jest istnienie zegarów okołodobowych w miejscach bezpośrednio regulujacych te procesy. Faktycznie, zarówno neurony miejsca najdalszego, jak i jadra pasma samotnego wykazuja silne właściwości zegarowe zarówno na poziomie długotrwałej ekspresji genów zegarowych, jak i aktywności elektrycznej, która osiaga swoje maksimum tuż przed rozpoczęciem behawioralnie aktywnej fazy ciemnej u zwierząt o aktywności nocnej (gryzoni). Dodatkowo, $z$ pomoca modelu mysiego PER2::LUC wykazano, że oscylacje okołodobowe w ekspresji genów zegarowych sa endogenne, oddzielne w obu strukturach. Chirurgiczne przecięcie połaczenia pomiędzy miejscem najdalszym a jacdrem pasma samotnego nie powoduje zaniku rytmów w żadnej ze struktur w warunkach hodowli pozaustrojowej. Co jednak niezwykle ciekawe, po takim zabiegu eksperymentalnym, prawidłowy, okołodobowy okres rytmów w jądrze pasma samotnego jest istotnie skrócony, co dowodzi modulacji rytmiki tego ośrodka neuronalnego przez miejsce najdalsze (którego parametry okołodobowe nie ulegaja zmianie po izolacji chirurgicznej). Tak więc, grzbietowy kompleks nerwu błędnego to nowoodkryty wielo-oscylatorowy ośrodek zegarowy w pniu mózgu, którego prawidłowe odmierzanie czasu zależy od wzajemnych połaczeń między jego komponentami (Chrobok i współaut, obserwacje nieopublikowane).

Funkcjonalnie, zegar okołodobowy w pniu mózgu, może przygotowywać zwierzę na nadejście fazy aktywnej, a tym samym prawidłowy odbiór informacji zwiazanych $z$ pobieraniem pokarmu. Wykazano, że neurony w jądrze pasma samotnego zwiększaja w fazie aktywnej ekspresję receptorów oraz w konsekwencji wrażliwość na peptydy, będace sygnałami sytości (cholecystokinina) i głodu (oreksyny, grelina). Dodatkowo, na poczatku fazy aktywnej rozszczelnieniu ulega ścisła bariera glejowa, dzielaca miejsce najdalsze (narzad okołokomorowy) od jądra pasma samotnego. Tym samym, informacje niezatrzymywane przez barierę krew-mózg (upośledzoną w narządach okołokomorowych), moga 
swobodnie penetrować $\mathrm{w}$ głąb parenchymy mózgu, ale tylko w określonym, okołodobowym oknie czasowym. Można więc założyć, że jądro pasma samotnego jest „okołodobowo zmiennym" narzadem okołokomorowym, gdyż pełni takie funkcje jedynie $\mathrm{w}$ fazie aktywnej (Chrobok i współaut., obserwacje nieopublikowane). Na zwiazek zegara w jądrze pasma samotnego $z$ metabolizmem wskazuja również badania pokazujące znaczne obniżenie amplitudy rytmów ekspresji genów zegarowych u myszy otyłych, karmionych dieta wysokotłuszczową (KANEKO i współaut. 2009).

\section{NIENEURONALNE ZEGARY OKOŁODOBOWE W MÓZGU}

Przez wiele dziesięcioleci neurony postrzegane były jako najistotniejsze komórki mózgowia, kontrolujące wszystkie procesy fizjologiczne i behawioralne. Komórki glejowe, które stanowia przynajmniej tak samo liczna populację komórkowa mózgowia jak neurony, były uważane za komórki podporowe, odżywcze i wspomagające pracę neuronów. Coraz więcej dowodów literaturowych wskazuję na równie ważna, choć odmienna rolę komórek glejowych w funkcjonowaniu układu nerwowego ('́́MIAEKOWSKA i DOMIN 2015, VERKHRATSKY i współaut. 2019). Dlatego najnowsze badania chronobiologiczne skupiaja się $\mathrm{w}$ równym stopniu na charakterystyce zegarów okołodobowych zarówno w komórkach nieneuronalnych, jak i w neuronach (Chi-Castañeda i ORTEGa 2016).

Najbardziej jaskrawe dowody potwierdzajace znaczenie zegarów okołodobowych w komórkach glejowych, dostarczaja badania samego SCN. W obrębie tej struktury, gęsto upakowanej przez najmniejsze w układzie nerwowym neurony, liczną populację stanowia astrocyty, silnie rozgałęzione komórki glejowe, dzielace $\mathrm{SCN}$ na kontrolowane przez siebie strefy, połaczone między soba za pomoca połaczeń szczelinowych (ang. gap junctions). Już pierwsze badania nad astrocytami SCN pokazały, że zablokowanie aktywności i proliferacji astrocytów zaburza rytmike okołodobowa in vivo (PROSSER i współaut. 1994). Wykazano też, że pojedyncze astrocyty SCN posiadaja ekspresję wszystkich głównych genów zegarowych, a więc stanowia druga populację komórek zegarowych SCN. Co ciekawe, molekularny mechanizm pętli transkrypcyjno-translacyjnej genów zegarowych astrocytów, tylko nieznacznie różni się od podobnego mechanizmu w neuronach. Okołodobowy okres oscylacji astrocytów w izolacji od neuronów jest istotnie krótszy (o niecałe dwie godziny). Najnowsze eksperymenty, publikowane na łamach najbardziej prestiżowych czasopism naukowych, pokazuja bardzo duże zainteresowanie środowiska tym tematem. To dowód nieoczekiwanej, zaskakujacej roli astrocytów w regulacji okołodobowej rytmiki zachowania zwierzat (BARCA-MAYO i współaut. 2017, BRANCACCIO i współaut. 2017). Badania $z$ użyciem modeli zwierzęcych, w których dokonano specyficznego wyłączenia ekspresji genów zegarowych w neuronach SCN, przy pozostawieniu funkcjonalnej aktywności zegara $\mathrm{w}$ astrocytach pokazały, że zwierzęta te wykazuja rytmiczne zachowania $\mathrm{i}$ to nawet w ciemności. Jest to dowód, że endogenny zegar $\mathrm{w}$ astrocytach jest wystarczajacy do odmierzania czasu w SCN. Jednak po zablokowaniu u tych zwierzat komunikacji między „tykajacymi” astrocytami a pozbawionymi zegara neuronami SCN, rytmiczność ich zachowania została utracona. To neurony SCN, ze względu na wydzielane przez siebie substancje humoralne i unerwienie nawet dalekich struktur mózgowia, sa potrzebne i niezbędne, aby informować cały organizm o fazie zegara (BRANCACCIO i współaut. 2019). Najprawdopodobniej, „podwójny” (neuronalno-astrocytarny) zegar w SCN stabilizuje jego rytm, wyznaczajac prawidłowy okres, zgodny $\mathrm{z}$ czasem słonecznym oraz kompensuje ewentualne zburzenie molekularnego zegara $\mathrm{w}$ jednej $\mathrm{z}$ dwóch (neuronalnej czy astrocytarnej) subpopulacji komórek nerwowych.

Astrocyty to nie jedyne, poza neuronami, komórki mózgowia, które dzięki ekspresji genów zegarowych sa w stanie odmierzać czas okołodobowy. Należą do nich również ependymocyty, wyspecjalizowane, urzęsione komórki glejowe wyściełające komory mózgu. Niezwykle silna rytmikę okołodobową w ekspresji genu Per2 wykazano dla warstwy komórek ependymy zarówno w pobliżu SCN (komora trzecia) czy w podstawno-przyśrodkowym podwzgórzu (komora trzecia), jak i w grzbietowym kompleksie nerwu błędnego (komora czwarta mózgu). Komórki te, podobnie jak astrocyty, charakteryzuja się krótszym endogennym okresem rytmu ex vivo, który także nie zależy od aktywności neuronalnej, występuje bowiem przy zablokowanej aktywności elektrycznej komórek nerwowych. Przypuszcza się, że rytmiczność endogennie oscylujacych komórek wyściółki, synchronizowana jest przez liczne połączenia szczelinowe między nimi. Bardzo interesujace, a do tej pory nie wyjaśnione, jest znaczenie przeciwfazowej obecności akrofazy ekspresji Per2 w ependymocytach, w stosunku do jej występowania w ośrodkach neuronalnych. W tych pierwszych, maksimum ekspresji rejestrowane jest pod koniec fazy ciemnej, a w drugich - pod koniec fazy jasnej. (YASUO i współaut. 2008, GuildiNG i współaut. 2009). 
Najciekawszym i najsilniejszym nieneuronalnym oscylatorem okołodobowym mózgowia jest splot naczyniówkowy (ang. choroid plexus), którego dobowe oscylacje ekspresji genów zegarowych są bardziej długotrwałe i o wyższej amplitudzie, nawet od tych rejestrowanych w SCN. Splot naczyniówkowy składa się $z$ bardzo licznych, ściśle połaczonych ze soba zmodyfikowanych komórek ependymy, które tworza kalafiorowate twory zanurzone w płynie mózgowo-rdzeniowym, w każdej z czterech komór mózgowia. Ze względu na budowę i funkcję, splot naczyniówkowy zalicza się do wydzielniczych (w przeciwieństwie do zmysłowych) narząóow okołokomorowych. Struktury te sa silnie unaczynione, a ich podstawowa funkcja jest przesaczanie osocza krwi, a więc ciagłe odnawianie płynu mózgowo-rdzeniowego wypełniającego komory mózgowia, który jest nieustannie absorbowany przez ziarnistości pajęczynówki $z$ powrotem do układu krwionośnego. Skład chemiczny i szybkość produkcji płynu mózgowo-rdzeniowego ma wyraźny profil okołodobowy. Zwiększona jego produkcja i reabsorbcja zachodzi podczas snu, w celu eliminacji metabolitów zgromadzonych podczas fazy aktywnej zwierzecia, co jest integralna częścią odkrytego niedawno układu glimfatycznego mózgu ssaków (XIE i współaut. 2013, MYUnG i współaut. 2018a).

Wyniki ostatnich badań pokazały, że zmodyfikowane komórki ependymy, tworzace sploty naczyniówkowe mózgu, maja silne endogenne właściwości zegarowe. Okres okołodobowej ekspresji ich genów zegarowych jest istotnie krótszy od okresu rytmów neuronalnych, a podobny do rejestrowanego w komórkach glejowych. Warto jednak wyraźnie zaznaczyć, że skrawki zawierające SCN pochodzace od myszy PER2::LUC, również nie wykazuja okresu oscylacji genów zegarowych idealnie zgodnego $z$ tym, jaki rejestrujemy w okołodobowej aktywności lokomotorycznej zwierzęcia. Okres rytmu SCN w warunkach ex vivo, a więc po odcięciu od reszty oscylatorów mózgowia, wynosi powyżej 24 godzin. Natomiast, okres rytmu okołodobowej aktywności tych zwierzat w stałej ciemności (w warunkach działania rytmu endogennego bez wpływu środowiska) wynosi około 23,7 godziny. Ta wyraźna rozbieżność w długości okresu, wyjaśniona została dopiero wtedy, kiedy w hodowli skrawków myszy PER2::LUC zawierajacych SCN (okres rytmu ponad 24h) umieszczono splot naczyniówkowy (okres rytmu poniżej 23h), kładac go na skrawku z SCN. Taka „manipulacja” nie zmieniła okresu rytmiki splotu naczyniówkowego, lecz istotnie skróciła okres oscylacji okołodobowych w SCN, zbliżajac go do tego, jaki rejestrowany jest w rytmie okołodobowej aktywności behawioralnej zwierzęcia. Obserwacje te potwierdzone zostały także w warunkach in vivo. Selektywne zablokowanie ekspresji genów zegarowych w splocie naczyniówkowym spowodowało znaczne wydłużenie okresu rytmu okołodobowej aktywności lokomotorycznej, podobne do okresu oscylacji SCN w hodowli. Podsumowujacc, nieneuronalne komórki splotu naczyniówkowego, przez uwalnianie nieznanych jak dotąd czynników dyfundujacych $\mathrm{w}$ płynie mózgowo-rdzeniowym, wpływaja okołodobowo na fazę głównego zegara, synchronizując jego okres tak, aby zapewnić prawidłowa rytmikę procesów fizjologicznych i zachowania zwierzat. Badania te sa kolejnym dowodem potwierdzajacym znaczenie nieneuronalnych zegarów mózgowia, które dostrajaja pracę zegarów neuronalnych. Co więcej, doniesienia o jednokierunkowym wpływie splotu naczyniówkowego na SCN poddaja $\mathrm{w}$ wattpliwość omnipotencję SCN i jego dominujaca pozycję w hierarchii mechanizmu rytmów biologicznych, jako nadrzędnego zegara biologicznego ssaków (MYung i współaut. 2018 a, b).

Silnym i trwałym oscylatorem nieneuronalnym jest także wyniosłość pośrodkowa (ang. median eminence), inny wydzielniczy narzad okołokomorowy zlokalizowany w brzusznej części podwzgórza, tuż pod jądrem łukowatym (Ryc. 1). Podobnie, jak w omawianej wcześniej charakterystyce rytmów komórek glejowych, oscylacje wyniosłości pośrodkowej sa także niewrażliwe na farmakologiczna blokadę aktywności elektrycznej otaczajacych ja jąder neuronalnych, pozostajacc w stosunku do nich w przeciwfazie. Znaczenie rytmiki okołodobowej wyniosłości pośrodkowej jest ciagle słabo poznane, jednak przypuszcza się, że może ona modulować funkcje neuroendokrynne tej struktury mózgowia (GUILDing i współaut. 2009).

\section{ZNACZENIE NAJNOWSZYCH BADAŃ CHRONOBIOLOGICZNYCH I ISTOTNOŚĆ TEORII WIELO-OSCYLATOROWEJ}

Wydaje się, że zegary okołodobowe maja ogromne znaczenie w podstawowym funkcjonowaniu organizmów żywych, gdyż w procesie ewolucji utrwaliły się u bardzo różnorodnych form życia, wykorzystujących zróżnicowane strategie przetrwania, manifestujące się w ich odmiennej fizjologii i zachowaniu. Zaburzenie okołodobowej homeostazy może być i jest przyczyna rozległych nieprawidłowości w ich funkcjonowaniu (GóRA 2015, MASRI i SASSONE-CORSI 2018, SHAN i wspó1aut. 2018, Wefers i współaut. 2018). Problem ten szczególnie dotyczy współczesnego świata i ludzi żyjacych w środowisku o sztucznym niekontrolowanym oświetleniu, 
nieograniczonym dostępie do pożywienia, nieregularnym czasie jego spożywania, braku presji drapieżników, a także co wydaje się bardzo istotne, zmiennych porach snu i czuwania. W konsekwencji, regularne i cykliczne zmienne środowiskowe, które przez miliony lat kształtowały nas w procesie ewolucji, zostały w dzisiejszym świecie bardzo zatarte.

Szczególnie trudne („niezrozumiałe”) dla naszego zegara biologicznego, a także bardzo szkodliwe dla naszego organizmu sa szybkie zmiany fazy naszej aktywności zwiąane $z$ podróżami przez wiele stref czasowych. Zespół nagłej zmiany strefy czasowej (ang. jet lag) to zaburzenie rytmiki okołodobowej wywołane adaptacja do nowego, szybko pojawiającego się fotoperiodu, który "zmusza" nasz organizm do nowego schematu aktywności dobowej. Nasz endogenny zegar biologiczny musi dostosować się do skokowej, szybkiej zmiany środowiskowej, która w naturalnej sytuacji nie występuje i ewolucyjnie nie została utrwalona. Po upływie kilku dni (około 1 dzień/godzinę zmiany czasowej w podróży na zachód i 1,5 dnia/godzinę zmiany w podróży na wschód), faza zegara biologicznego synchronizuje się do nowego cyklu środowiskowego. Jest to możliwe dzięki elastyczności zegara, wykorzystywanej w naturalnych warunkach np. przy zmianie jego fazy $w$ sezonowych różnicach fotoperiodu. Skokowe, nagłe zmiany fotoperiodu, sa zbyt szybkie w stosunku do wolnej, ewolucyjnie ukształtowanej adaptacji zegara do nowych warunków. Wyniki ostatnich badań pokazuja, że za mechanizm zjawiska ,jet lag” nie odpowiada jedynie desynchronizacja neuronów zegarowych w obrębie $\mathrm{SCN}$, które powoli synchronizuja faze swojego endogennego rytmu do nowego środowiska. Problem jest zdecydowanie bardziej skomplikowany, gdyż każdy endogenny oscylator okołodobowy w mózgu jak i poza nim, w tkankach i narzadach ciała, musi także dostosować fazę swojej aktywności do nowego środowiska. Niektóre $z$ nich dostosowują się wolniej, inne szybciej. Jedne sa regulowane przez nowy reżim oświetlenia, a inne przez nowa porę posiłków czy interakcje międzyludzkie. To właśnie te procesy desynchronizacji i resynchronizacji wielu oscylatorów, zarówno na poziomie pojedynczych neuronów je budujacych, jak też interakcji między neuronami i glejem, czy w końcu pomiędzy poszczególnymi oscylatorami w mózgowiu, a zegarami obwodowymi, kształtują w sumie przebieg zjawiska „jet lag” (WATERHOUSE i współaut. 2007, ARENDT 2009, Auger i MorgenthaleR 2009).

Problem „jet lag” nie dotyczy jedynie ludzi odbywających dalekie podróże $z$ szybkim przekraczaniem wielu stref czasowych. Ten sam mechanizm wewnętrznej desynchronizacji obserwujemy także u pracowników zmianowych, którzy zmuszeni sa do zmiany pory swojej aktywności dobowej, często wiele razy w ciagu miesiacca. W takiej sytuacji mamy do czynienia $z$ warunkami ciagłego „jet lagu” (ang. constant jet lag) który, jak dowiodły liczne badania na gryzoniach i ludziach, ma szczególnie poważne konsekwencje zdrowotne. Częste spożywanie posiłków przez pracowników zmianowych w czasie, kiedy organizm nie jest na to przygotowany, przyczynia się do wykształcenia u nich syndromu metabolicznego, otyłości czy chorób sercowo-naczyniowych. Innymi, socjoekonomicznymi skutkami wewnętrznej desynchronizacji w warunkach pracy zmianowej jest jej obniżona wydajność, która w przypadku np. pracowników służby zdrowia, może mieć również bezpośredni wpływ na zdrowie i życie pacjentów. Badania na gryzoniach w warunkach ciagłego „jet lagu” pokazały nawet ich istotnie podwyższona śmiertelność (KWARECKI i ZuŻEWICZ 2001, ERREN i współaut. 2010, REID i ABBOtT 2015, WoŁYNIEC i współaut. 2015).

Problem zjawiska „jet lag” obejmuje również ludzi pracujacych w stałych godzinach, ale niepracujacych w weekendy, oraz młodzież szkolną. Ostatnio modne i nowe pojęcie "social jet lag" opisuje cotygodniowe zaburzenia rytmiki okołodobowej, zwiazane ze zmiana godzin snu i czuwania w zależności od dnia tygodnia. Najczęściej opóźniamy swój rytm w weekendy, a przyspieszamy go na początku tygodnia. Tendencja ta wynika $z$ kilku współwystępujacych czynników. Po pierwsze, endogenny rytm okołodobowy większości ludzi ma (w przeciwieństwie do gryzoni) okres przekraczajacy 24 godziny i stad nasza naturalna predyspozycja do wydłużania rytmu aktywności dobowej. Dodatkowo, atrakcyjność bodźców środowiskowych (kontekst społeczno-kulturowy) nie zachęca nas do wczesnego odpoczynku, jeśli nie jesteśmy zmuszeni wstać następnego dnia, aby zdążyć do pracy lub szkoły. Badania pokazuja jednak, że nawet prawidłowa liczba godzin snu w czasie weekendu, ale o nieprawidłowej porze doby, ma swoje konsekwencje zdrowotne i może przyczyniać się do większego prawdopodobieństwa zapadalności na choroby sercowo-naczyniowe i nowotwory oraz zmniejsza wydajność na początku tygodnia, kiedy musimy przyspieszyć swój endogenny rytm (JANKOWSKI 2017, TAKAHASHI i współaut. 2018).

Dlatego dokładne poznanie i zrozumienie pracy mechanizmu zegara biologicznego, zarówno na poziomie jego pojedynczych oscylatorów oraz wzajemnych anatomicznych, 
jak i funkcjonalnych powiązań między nimi, jest szczególnie istotne w wypracowaniu efektywnej strategii radzenia sobie ze zjawiskiem ,jet lag”, które dalej pozostaje wyzwaniem dla współczesnej chronobiologii. Przyszłe badania $w$ tej dziedzinie neuronauki powinny skupić się nie tylko na opisie pracy poszczególnych zegarów okołodobowych organizmu, ale także na poznaniu mechanizmów synchronizacji poszczególnych zegarów przez specyficzne bodźce środowiskowe. Ciągle otwartym pozostaje także pytanie, w jaki sposób rozproszone po całym mózgowiu i ciele komórki odmierzajace czas okołodobowy komunikują się ze sobą. Odpowiedź na nie, pozwoliłaby na opracowanie sposobów ich lepszej synchronizacji. Ostatnie odkrycia, pokazujace skomplikowaną sieć zegarów okołodobowych, a także coraz bardziej akceptowana przez środowisko naukowe teoria wielo-oscylatorowa, wydaja się być zdecydowanym krokiem w dobra stronę - ostatecznego zrozumienia neuronalnego mechanizmu rytmiki okołodobowej.

\section{Streszczenie}

Cyklicznie zmieniające się warunki środowiska wywoływane obrotowym ruchem Ziemi sa niezmiernie ważnym czynnikiem w procesie ewolucyjnym. Dlatego organizmy żywe wykształcily mechanizmy zwane zegarami biologicznymi, które pozwalaja im nie tylko biernie na nie reagować, ale je przewidywać i adaptować do nich swoje procesy fizjologiczne oraz zachowania okołodobowe. Historycznie, jądra nadskrzyżowaniowe podwzgórza (ang. suprachiasmatic nuclei, SCN) uważane były za główny i jedyny zegar okołodobowy ssaków. Powszechne było przekonanie, że rytmiczna ekspresja genów zegarowych tego jądra i dobowe zmiany jego aktywności elektrycznej kontrolują wszystkie procesy rytmiczne organizmu. Nowe odkrycia kwestionuja jednak teorię dominacji jednego oscylatora. Istnieje coraz więcej dowodów potwierdzających obecność i funkcjonowanie neuronalnych i nie-neuronalnych, niezależnych od SCN, endogennych oscylatorów zegara biologicznego, zlokalizowanych w wielu miejscach mózgowia i poza nim. W artykule opisujemy i charakteryzujemy nowo odkryte autonomiczne zegary mózgowia. Przedstawiamy dowody popierające teorię wielo-oscylatorową i jej rolę w zrozumieniu mechanizmu zegara biologicznego, w kontekście powszechności i znaczenia rytmów biologicznych w fizjologii i patologii funkcjonowania organizmu człowieka.

\section{LITERATURA}

Abe M., Herzog E. D., Yamazaki S., Straume M., TeI H., SAKaki Y., MenaKer M., Block G. D., 2002. Circadian rhythms in isolated brain regions. J. Neurosci. 22, 350-356.

ABRAHAMSON E. E., MOORE R. Y., 2001. Suprachiasmatic nucleus in the mouse: retinal innervation, intrinsic organization and efferent projections. Brain Res. 916, 172-191.

ALBRECHT U., 2012. Timing to perfection: The biology of central and peripheral circadian clocks. Neuron 74, 246-260.
ARENDT J., 2009. Managing jet lag: Some of the problems and possible new solutions. Sleep Med. Rev. 13, 249-256.

Auger R. R., Morgenthaler T. I., 2009. Jet lag and other sleep disorders relevant to the traveler. Travel Med. Infect. Dis. 7, 60-68.

BAÑo-OtÁloRA B., Piggins H. D., 2017. Contributions of the lateral habenula to circadian timekeeping. Pharmacol. Biochem. Behav. 162, 46-54.

Barca-Mayo O., Pons-Espinal M., Follert P., ARMIROTTI A., BERDONDINI L., DE PIETRI TONELLI D., 2017. Astrocyte deletion of Bmal1 alters daily locomotor activity and cognitive functions via GABA signalling. Nat. Commun. 8, 1-14.

BRANCACCIO M., PATTON A. P., CHESHAM J. E., MAYWOOD E. S., Hastings M. H., 2017. Astrocytes control circadian timekeeping in the suprachiasmatic nucleus via glutamatergic signaling. Neuron 93, 1420-1435.

BRANCACCIO M., EdWARdS M. D., PATTON A. P., SMYllie N. J., ChEShaM J. E., MAYWOOD E. S., Hastings M. H., 2019. Cell-autonomous clock of astrocytes drives circadian behavior in mammals. Science 363, 187-192.

CHALlET E., 2015. Keeping circadian time with hormones. Diabetes Obes. Metab. 17, 76-83.

CHALlET E., 2019. The circadian regulation of food intake. Nat. Rev. Endocrinol. 15, 393-405.

Cheng M. Y., Bullock C. M., Li C., Lee A. G., BERMAK J. C., BELluzzi J., WEAVER D. R., LESLIE F. M., ZHOU Q. Y., 2002. Prokineticin 2 transmits the behavioural circadian rhythm of the suprachiasmatic nucleus. Nature 417, 405-410.

ChI-CASTAÑEDA D., ORTEGA A., 2016. Clock genes in glia cells: A rhythmic history. ASN Neuro. $8,5$.

COLWELL C. S., 2011. Linking neural activity and molecular oscillations in the SCN. Nat. Rev. Neurosci. 12, 553-569.

DibNer C., SCHIBler U., Albrecht U., 2010. The mammalian circadian timing system: organization and coordination of central and peripheral clocks. Annu. Rev. Physiol. 72, 517-549.

Erren T. C., Falaturi P., Morfeld P., KnaUth P., REITER R. J., PIEKARSKI C., 2010. Shift work and cancer: the evidence and the challenge. Dtsch. Arztebl. Int. 107, 657-662

GIEBULTOWICZ J. M., 2018. Mechanism of circadian clock. The 2017 Nobel Prize in physiology or medicine. Kosmos 67, 245-249.

GizOWSKI C., BOUROUE C. W., 2017. The neural basis of homeostatic and anticipatory thirst. Nat. Rev. Nephrol. 14, 11-25.

Gizowski C., ZAELZER C., BOuRQue C. W., 2016. Clock-driven vasopressin neurotransmission mediates anticipatory thirst prior to sleep. Nature 537, 685-688.

GOOLEY J. J., SCHOMER A., SAPER C. B., 2006. The dorsomedial hypothalamic nucleus is critical for the expression of food-entrainable circadian rhythms. Nat. Neurosci. 9, 398-407.

GóRA M., 2015. Chronopsychologia $w$ zarysie-przeglad badań $i$ praktycznych zastosowań. Wszechświat 116, 258-263.

GÓRSKA-ANDRZEJAK J., 2011. Jak” tyka” zegar biologiczny. Wszechświat 112, 109-114.

Granados-Fuentes D., Prolo L. M., Abraham U., HERZOG E. D., 2004a. The suprachiasmatic nucleus entrains, but does not sustain, circadian rhythmicity in the olfactory bulb. J. Neurosci. 24, 615-619.

Granados-Fuentes D., SaXena M. T., Prolo L. M., Aton S. J., HerzoG E. D., 2004b. Olfactory bulb neurons express functional, entrain- 
able circadian rhythms. Eur. J. Neurosci. 19, 898-906.

Granados-Fuentes D., Tseng A., Herzog E. D., 2006. A circadian clock in the olfactory bulb controls olfactory responsivity. J. Neurosci. 26, 12219-1225.

GRILL H. J., HAYES M. R., 2012. Hindbrain neurons as an essential hub in the neuroanatomically distributed control of energy balance. Cell Metab. 16, 296-309.

GUILDING C., PIGGINS H. D., 2007. Challenging the omnipotence of the suprachiasmatic timekeeper: Are circadian oscillators present throughout the mammalian brain? Eur. J. Neurosci. 25, 3195-3216.

Guilding C., Hughes A. T., Brown T. M., Namvar S., Piggins, H. D., 2009. A riot of rhythms: neuronal and glial circadian oscillators in the mediobasal hypothalamus. Mol. Brain 2, 28.

Guilding C., HugHes A. T., Piggins H. D., 2010. Circadian oscillators in the epithalamus. Neuroscience 169, 1630-1639.

Hastings M. H., MaYwood E. S., BRANCACCIO M., 2018. Generation of circadian rhythms in the suprachiasmatic nucleus. Nat. Rev. Neurosci. $19,453-469$

Huang L., Xi Y., Peng Y., Yang Y., Huang X., Fu Y., TAO Q., XIAO J., YUAN T., AN K., ZHAO H., Pu M., Xu F., Xue T., LuO M., So K. F., ReN C., 2019. A visual circuit related to habenula underlies the antidepressive effects of light therapy. Neuron. 102, 128-142.

JANKOWSKI K. S., 2017. Social jet lag: Sleep-cor rected formula. Chronobiol. Int. 34, 531-535.

Kaiser C., KaUfmanN C., LeUtRitz T., ARNOLD Y. L., SPECK O., Ullsperger M., 2019. The hu man habenula is responsive to changes in luminance and circadian rhythm. Neuroimage 189, 581-588.

KANEKO K., YAMADA T., TSUKITA S., TAKAHASHI K., ISHIGAKI Y., OKA Y., KATAGIRI H., 2009. Obesity alters circadian expressions of molecular clock genes in the brainstem. Brain Res. $1263,58-68$.

KWARECKI K., ZuŻEWICZ K., 2001. Najczestsze klopoty zdrowotne pracownika zmianowego. Bezp. Pracy 9, 30-31.

Langlet F., Mullier A., Bouret S. G., Prevot V., DEHOUCK B., 2013. Tanycyte-like cells form a blood-cerebrospinal fluid barrier in the circumventricular organs of the mouse brain. J. Comp. Neurol. 521, 3389-3405.

LEWANDOWSKI M. H., 1999. Zegar biologiczny u ssaków: struktura i funkcja. Post. Hig. Med. Dośw. 53, 405-422.

LEWANDOWSKI M. H., 2008. A nonspecific system provides nonphotic information for the biological clock. [W:] Visual Transduction and Non-Visual Light Perception. TOMBRAN-TINK J., BARNSTABLE C. J. (red.). Humana Press, 465-480.

LUCAS R. J., 2013. Mammalian inner retinal photoreception. Curr. Biol. 23, 125-133.

MASRI S., SASSONE-CORSI P., 2018. The emerging link between cancer, metabolism, and circadian rhythms. Nat. Med. 24, 1795-1803.

MCKinleY M. J., MCALlEN R. M., DAVERN P., Giles M. E., Penschow J., Sunn N., UschaKOV A., OLDFIELD B. J., 2003. The sensory circumventricular organs of the mammalian brain. [W:] Advances in anatomy, embryology, and cell biology. Springer-Verlag Berlin Heidelberg, 172, 1-122.

MOORE R. Y., EICHLER V. B., 1972. Loss of a cir cadian adrenal corticosterone rhythm following suprachiasmatic lesions in the rat. Brain Res. 42, 201-206.
MOORE-EDE M. C., 1986. Physiology of the circadian timing system: predictive versus reactive homeostasis. Am. J. Physiol. 250, 737-752.

MYUNG J., SCHMAL C., HONG S., TSUKIZAWA Y., Rose P., Zhang Y., HoltzMan M. J., DE SCHuTTER E., HERZEL H., BORDYugOV G., TAKUMI T., 2018a. The choroid plexus is an important circadian clock component. Nat. Commun. 9, 1-13.

Myung J., Wu D., Simonneaux V., Lane T. J., 2018b. Strong circadian rhythms in the choroid plexus: implications for sleep-independent brain metabolite clearance. J. Exp. Neurosci. $12,1-4$.

Myung J., Wu M-J., LeE C-Y., RAHIM A. R., TRUONG V. H., WU D., Piggins H. D., WU M-S., 2019. The kidney clock contributes to timekeeping by the master circadian clock. Int. J. Mol. Sci. 20, 2765.

NOLASCO N., JUÁREZ C., MORGADO E., MEZA E., CABA M., 2012. A circadian clock in the olfactory bulb anticipates feeding during food anticipatory activity. PLoS One 7, e47779.

NoRTHEAST R. C., CHROBOK L., Hughes A. T. L., Petit C., Piggins, H. D., 2019. Keeping time in the lamina terminals: novel oscillator properties of forebrain sensory circumventricular organs. FASEB J. doi: 10.1096/fj.201901111R

Paul J. R., Davis J. A., Goode L. K., Becker B. K., FUSIliER A., MEADOR-WoOdRUFF A., GAMBLE K. L., 2019. Circadian regulation of membrane physiology in neural oscillators through out the brain. Eur. J. Neurosci. doi: 10.1111/ ejn. 14343.

PAVlOVSKI I., EVANS J. A., Mistlberger R. E., 2018. Feeding time entrains the olfactory bulb circadian clock in anosmic PER2::LUC mice. Neuroscience 393, 175-184.

Prosser R. A., Edgar D. M., Heller H. C., MillER J. D., 1994. A possible glial role in the mammalian circadian clock. Brain Res. 643, 296-301

RALPH M. R., MENAKER M., 1988. A mutation of the circadian system in golden hamster. Science 241, 1225-1227.

Ralph M. R., Foster R. G., Davis F. C., Menaker M., 1990. Transplanted suprachiasmatic nucleus determines circadian period. Science 247, 975-978.

REID K. J., ABBOTT S. M., 2015. Jet lag and shift work disorder. Sleep Med. Clin. 10, 523-535.

SAKHI K., BELle M. D., Gossan N., DelagRANGE P., PigGins H. D., 2014a. Daily variation in the electrophysiological activity of mouse medial habenula neurones. J. Physiol. 592, 587603.

SAKHI K., Wegner S., Belle M. D., Howarth M., Delagrange P., BRown T. M., Piggins H. D., 2014b. Intrinsic and extrinsic cues regulate the daily profile of mouse lateral habenula neuronal activity. J. Physiol. 592, 5025-5045.

Shan Z., Li Y., ZONG G., GUO Y., Li J., MANSON J. E., Hu F. B., Willett W. C., SchernhaMMER E. S., BHUPATHIRAJU S. N., 2018. Rotating night shift work and adherence to unhealthy lifestyle in predicting risk of type 2 diabetes: results from two large US cohorts of female nurses. BMJ 363, k4641.

ŚMIALKOWSKA M., DOMIN H., 2015. Astrocyty a intelekt. Wszechświat 116, 204-209.

STEPHAN F. K., ZUCKER I., 1972. Circadian rhythms in drinking behaviour and locomotor activity of rats are eliminated by hypothalamic lesions. Proc. Natl. Acad. Sci. USA 69, 15831586. 
TAKAHASHI J. S., 2017. Transcriptional architecture of the mammalian circadian clock. Nat. Rev. Genet. 18, 164-179.

TAKAHASHI M., TAHARA Y., TSUBOSAKA M., FUKAZAWA M., OZAKI M., IWAKAMI T., NAKAOKA T., SHIBATA S., 2018. Chronotype and social jetlag influence human circadian clock gene expression. Sci. Rep. 8, 10152.

VERKHRATSKY A., HO M. S., ZOREC R., PARPURA V., 2019. The concept of neuroglia. Adv. Exp. Med. Biol. 1175, 1-13.

WATERHOUSE J., REILly T., ATKINSON G., EDWARDS B., 2007. Jet lag: trends and coping strategies. Lancet 369, 1117-1129.

Wefers J., VAN MOORSEL D., HANSEN J., CONNELL N. J., HaVekes B., HoEkS J., VAN MARKEN Lichtenbelt W. D., Duez H., Phielix E., KalsBeEK A., Boekschoten M. V., HoOIVEld G. J., Hesselink M. K. C., Kersten S., Staels B., ScheEr F. A. J. L., SCHRAUWEN P., 2018. Circadian misalignment induces fatty acid metabolism gene profiles and compromises insulin sensitivity in human skeletal muscle. Proc. Natl. Acad. Sci. USA 115, 7789-7794.

WOEYNIEC W., KURLAPSKI M., JANUSZCZYK J., RENKE M., 2015. Cukrzyca $w$ społeczeństwie 24/7. Zwiazek między praca zmianowa a za- burzeniami metabolicznymi. Diabetol. Klin. 4, 22-28.

Xie L., Kang H., Xu Q., Chen M. J., LiaO Y., THIYAGARAJAN M., O’DONNELL J., CHRISTENSEN D. J., NiChOlson C., IlifF J. J., TAKANO T., DEANE R., NEDERGAARD M., 2013. Sleep drives metabolite clearance from the adult brain. Science 342, 373-377.

Yasuo S., VON Gall C., Weaver D. R., KorF H. W., 2008. Rhythmic expression of clock genes in the ependymal cell layer of the third ventricle of rodents is independent of melatonin signaling. Eur. J. Neurosci. 28, 2443-2450.

Yoo S-H., YAMAZAKI S., LOWREY P. L., SHIMOMURA K., Ko C. H., BuHR E. D., SIEPKA S. M., Hong H. K., OH W. J., YOO O. J., Menaker M., TAKAHASHI J. S., 2004. PERIOD2::LUCIFERASE real-time reporting of circadian dynamics reveals persistent circadian oscillations in mouse peripheral tissues. Proc. Natl. Acad. Sci. USA 101, 5339-5346.

ZHAO H., RUSAK B., 2005. Circadian firing-rate rhythms and light responses of rat habenular nucleus neurons in vivo and in vitro. Neuroscience $132,519-528$.

KOSMOS Vol. 69, 1, 91-103, 2020

ŁukASz CHRobok, MaRian H. Lewandowski

Department of Neurophysiology and Chronobiology, Institute of Zoology and Biomedical Research, Faculty of Biology, Jagiellonian University in Krakow, 9 Gronostajowa Str., 30-397 Krakow, E-mail: lukasz.chrobok@uj.edu.pl; marian.lewandowski@uj.edu.pl

\section{MULTI-CLOCK MODEL OF THE MAMMALIAN CIRCADIAN CLOCK}

\section{Summary}

Cyclic changes in the environment evoked by Earth rotation are crucial factors for evolution. Therefore, living organisms developed specific mechanisms, named the biological clocks, that enable not only to passively react, but rather to organise physiological processes and behaviour around the day. Historically, the suprachiasmatic nuclei (SCN) of the hypothalamus were considered the main and only circadian oscillator in mammals, which rhythmic expression of clock genes and daily modulation of electrical activity control all rhythmic processes of the organism. Novel findings question the dominance of one oscillator, giving evidence for the involvement of SCN-independent, endogenous neuronal and non-neuronal clocks, located in multiple brain structures and throughout the body. Here, after characterising autonomous brain circadian oscillators, we show evidence for the relevance of a multi-clock model and its consequences for the understanding of growth and application of chronobiology in everyday life. 